\title{
ЗАВХАН АЙМГИЙН ЭКОСИСТЕМИЙН ТӨЛӨВ БАЙДЛЫН СУДАЛГААНЫ ЯВЦ, ҮР ДУНГЭЭС
}

\author{
Н.Нарантуяа ${ }^{1}$, З.Цогт ${ }^{1}$, Сафронова И.Н \\ 1 Ерөнхий болон сорильн биологийн хүрээлэн, Шинжлэх ухааны Академи, Монгол улс \\ 2 Санкт-Петербургийн Комаровын нэрэмжит Ботаникийн хүрээлэн, ОХУ \\ Цахим шуудан: narantuya_n@hotmail.com
}

\section{Хураангуй}

ЭнэхүҮ өгүҮлэлд Завхан аймгийн нутагт явуулсан “Завхан аймгийн ой, хээрийн экосистемийн төлөв байдал, нөлөөллийн үнэлгээ” судалгааны үр дүнг тусгав.

Судалгаагаар мод нилэнхүйд нь огтлолсны нөлөөгөөр мод огтолсон талбайн гадаргуугын усны урсаи хаврын улиралд 10-80 дахин, зуны улиралд 2-10 дахин ихэсч, хөрс эвдэрч, ойн ургамалжсил нуга, хээрийн ургамлаар солигдон ойн сэргэн ургалтанд таагүй нөлөө бүрдэж байгааг тогтоов.

Завхан аймгийн нутагт тайгажуу ба иармын бүслүүрийн ой тархаж, тэнд алаг өвс-ритид хөвд, ритид хөвд, алирс-ритид хөвд, сорвоо-ритид хөвд, улалж ритид хөвд, алирс-нэрс-аулакомниум хөвдөт хэвиинжийн иинэсэн ой зонхилж байна.

Төв Хангайн ойн насны бүтэи нийлмэл, байгалийн аясаараа солигдсон насны 2-3 үе удмаас тогтдог ба судалгааны талбайд тоологдсон модны 50-иас илүү хувь нь 230-310 насных байна. Иймд тухайн бүс нутагт түҮвэрлэх огтлолтыг ашиглах нь зүйтэй юм.

Хээрийн экосистемийн судалгаанаас үзэхэд, Завхан аймагт хээрийн нэг хэвиинж, өндөр уульлн хээр, уулын хээр, нугын хээр, хуурай хээр, иөлөрхөг хээр, иөлийн хээр гэсэн 6 дэд хэвиинжид хамаарсан 20 хэвшил тодорхойлж, мал хэт бэлчээрлэлтийн нөлөөгөөр талхлагдсан байдлыг аргазүйн дагуу үнэлж, Завхан аймгийн хэмжээнд хээрийн экосистемийн ашиглалт 3 баллын буюу экосистемийн нөлөөллийн дунд үнэлгээнд хамрагдаж байгааг тогтоов. 30 гаруй жилийн туршид атаршсан газрын ургамалжил шарилж-хиагт болон уетэн-шарилж-хиагт бүлгэмдэл болон байгалийн аясаар нөхөн сэргэж буйг судлан илруүлэв.

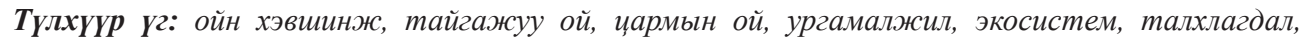
хэвиил, бүлгэмдэл, байгалийн нөхөн сэргэлт

\section{ОРШИЛ}

Судалгааны үндэслэл, шаардлага. Сүүлийн жилүүдэд цаг уурын өөрчлөгдөл, дулаарал, хуурайшлын нөлөө хуурай сэрүүн бүс нутагт оршдог манай оронд илүү мэдрэгдэж, дэлхийн дунджаас 3 дахин буюу $2.1^{\circ} \mathrm{C}$ хэмээр дулаарсан судалгааны үр дүнгүҮд гарсан байна (4).

Монгол улсад мал хувьчлагдаж түүний тоо толгойн өсөлт эрчимжих, ялангуяа зах зээлийн эрэлт хэрэгцээтэй уялдан мал сүргийн бүтэц, уламжлалт мал маллагааны зарчим алдагдах, уул уурхайн ашиглалт зэрэг хүний хүчин зүйлээс хамаарсан сөрөг нөлөөллүүд ургамал нөмрөг, бэлчээр, ургамалжлыг талхлах, доройтуулах нэгэн шалтгаан болсоор байна.

Завхан аймаг Монгол улсын баруун хойд хэсэгт дорнод уртрагийн $93^{\circ} 16^{\prime}$-аaс $99^{\circ} 12^{\prime}$, 
хойд өргөргийн 46033'-аaс 50²3' хооронд оршдог. Хойноос урд хүртэл 610 км, баруунаас зүүн хүртэл 520 км, 82.5 мянган км$^{2}$ нутаг дэвсгэртэй бөгөөд Хангайн нурууны өндөрлөгийн баруун хэсэг, Их нууруудын хотгорын зүүн, Монгол Алтайн нурууны салбар уулсын хойд хэсэгт оршиж, Өндөр уул, Уулын тайга, Уулын ойт хээр, Хээр, Цөлийн хээр гэсэн байгалийн 5 бүс бүслүүрийн ургамалжил тархдаг онцлогтой.

Завхан аймаг нь монгол орны хүйтэн бүс нутагт хамрагддаг ба хамгийн хүйтэн цэг нь $53 \mathrm{C}^{0}$ хүрч хүйтэрдэг Тосонцэнгэл сум юм. 1-р сарын агаарын дундаж температур $-20 \ldots-30{ }^{\circ} \mathrm{C}$, бөгөөд өндөр уулсаар жилд 400 мм, баруун хэсгээрээ 80-100 мм, бусад нутгаар 200-206 мм хур тунадас унадаг бүс нутаг (5). Сүүлийн 15 жилд агаарын температур олон жилийн дунджаас 0.7$2.5^{\circ} \mathrm{C}$ хэм дулаарсан, хур тунадас олон жилийн дунджаас 38-62 мм буюу 21.9$39.7 \%$ бага унасан зэрэг судалгааны үр дүнгүүд гарснаас үзвэл, Завхан аймгийн экосистем дулаарал, хуурайшлын нөлөөнд багагүй автсан нь харагдаж байна (4).

Иймд тодорхой бүс нутаг, аймаг, сумдын экосистемийн мониторингийн судалгаа зайлшгүй шаардлагатай бөгөөд үүнд үндэслэн тэдгээрийн өөрчлөгдөл, талхлагдах явцыг судлан тогтоох, ингэснээр орон нутгийн хөгжлийн хөтөлбөрт цаашид авах арга хэмжээний талаар тусгуулах ажил нэн чухал болж байгаа билээ.

Монгол улсын Шинжлэх ухааны академийн орон нутагтай хамтын ажиллагааны хүрээнд ШУА-ийн Ерөнхий болон сорилын биологийн хүрээлэнгийн Ботаникийн салбар, Монгол Оросын хамтарсан биологийн иж бүрэн экспедици (МОХБИБЭ), Завхан аймгийн ЗДТГ хамтарсан гэрээг 2014 онд байгуулсанаар тус аймгийн аймгийн экосистемийн судалгааг эхлүүлсэн билээ.

Cудалгааны зорилго: Завхан аймгийн нийгэм эдийн засгийг шинжлэх ухааны үндэслэлтэйгээр хөгжүүлэхэд “Биологийн олон янз байдал, экосистемийн төлөв байдлын иж бүрэн судалгаa"-ны үр дүнг нэвтрүүлэхэд оршино.

\section{Судалгааны зорилт:}

- Завхан аймгийн хээрийн бүсийн ургамалжлын төлөв байдал, экосистемийн нөлөөллийн $\mathrm{M:500,0}$ мянгын хэмжээст зургийн материал бүрдүүлэх

- Экосистемийн талхлагдлын зэргийг тогтоох: Үүнд:

- Байгалийн экосистемийн талхлагдлын зэргийг тогтоох

- Уул уурхай, зам харгуйн нөлөөгөөр эвдэрсэн газрын эвдрэлийн зэргийг тогтоох

- Атаржсан газрын үнэлгээ хийх, нөхөн сэргэлтийн байдлыг үнэлэх.

- Завхан аймгийн ойн сангийн өнөөгийн төлөв, цаашдын хандлагыг тогтоох зэрэг болно.

\section{Судалгааны объект, аргазүй.}

Хээрийн экосистемийн нөлөөллийн судалгааг Завхан аймгийн Их-Уул, Идэр, Нөмрөг, Баянхайрхан, Асгат, Баянтэс, Тэс, Сонгино, Цэцэн-Уул, Сантмаргац, Ургамал, Дөрвөлжин, Завханмандал, Эрдэнэхайрхан, Алдархаан, Отгон, Шилүүстэй, Цагаанчулуут, Цагаанхайрхан, Яруу, Тэлмэн, Тосонцэнгэл, Их-Уул зэрэг сумдын нутагт, ойн судалгааг Их-Уул, Тосонцэнгэл сумын нутагт 1976-1980 онд суурин, 1983, 1989, 2001, 2003, 2006, 2012, 2015 онд хагас суурин, Тэлмэн, Идэр, Улиастай, Алдархаан, Цагаан хайрхан, Цагаан чулуут, Улиастай, Яруу, Нөмрөг, Түдэвтэй, Баянхайрхан, Асгат, Баянтэс зэрэг сумдын ой бүхий нутагт гүйцэтгэв.

Судалгааны аргазүй. Экосистемийн нөлөөллийн зэргийг тогтоохдоо МОХБИБЭийн боловсруулсан 5 баллын үнэлгээний системийг ашиглав [11].

1 балл - байгалийн фон бүлгэмдэл буюу хүний хүчин зүйлийн нөлөөнд бага ашиглагдсан экосистем

2 балл - хүний хүчин зүйлсийн нөлөөнд 
дунд ашиглагдсан экосистем

3 балл - хүний хүчин зүйлсийн нөлөөнд их ашиглагдсан экосистем

4 балл - хүний хүчин зүйлсийн нөлөөнд хэт их ашиглагдсан

5 балл - талхлагдсан

Байгалийн экосистемд байгалийн болон хүний хүчин зүйлсийн нөлөөллийг үнэлсэн ерөнхий шалгуур үзүүлэлт нь ургамлын амьдрамж алдагдсан эсэх, бүлгэмдэл дэхь зонхилох ургамлын үүрэг, үндсэн бэлчээрийн чанарын өөрчлөгдөл, бүлгэмдлийн бүтэц, бүрэлдэхүүн бүрэн алдагдсан эсэх зэрэг байсан бөгөөд үзүүлэлт тус бүрийг нарийвчилсан үзүүлэлтээр хувиар эсвэл зүйлээр ялган үнэлсэн болно (11).

Байгалийн экосистемийн төлөв байдлын үнэлгээг маршрут аргаар явуулж, машины хөдөлгөөний явцад харагдах орчны хүрээнд сансрын зураг дээр авто зам, техникийн гаралтай, уул уурхай, барилга байгууламжийн нөлөөгөөр эвдэрсэн газар, түймэрт шатсан ой, бэлчээр зэрэг тодорхой өөрчлөлтүүдийг тэмдэглэж, шаардлагатай газруудад геоботаникийн дэлгэрэнгүй бичиглэлийг үйлдэв.

Геоботаникийн дэлгэрэнгүй бичиглэлийг бүлгэмдлийн зүйлийн олон янз байдал, бүлгэмдлийн ерөнхий болон зүйл ургамлын тусгагийн бүрхэц, арив, ургамлын өндөр, ургамлын хөгжлийн үе шат зэрэг үзүүлэлтүүдээр үйлдэв.

Ойн судалгааг тухайн бүс нутагт хамгийн өргөн тархсан хэвшинжийн ойд байнгын ажиглалтын ба түр хугацааны сорц талбай тусгаарлан сорил туршилтын ажил гүйцэтгэж, материал бүрдүүлэв. Судалгааны хугацаанд нийт 31 сорьц

\section{СУДАЛГААНЫ ҮР ДУН}

\section{Завхан аймгийн ойн экосистемийн судалгааны үр дүн}

Монгол орны ой мод Хангай, Хэнтий, Хөвсгөл, Монгол Алтайн уулсын системд хамрагдах ба ихэвчлэн шинэсэн ой талбай байгуулж, 626 ширхэг загвар мод авч, таксацын хэмжилт, бичиглэл үйлдсэн болно.

Сорьц талбай тусгаарлах, таксацын хэмжилт тооллого хийх, загвар мод авах болон хээрийн судалгааны анхдагч материалд боловсруулалт хийхэд А.В.Побединский (1962), Н.П.Анучин (1977) нарын өргөн хэрэглэгдэж буй аргазүйг ашиглав.

Сорьц талбайн хэмжээг ойн нас, нэгж талбай дахь модны тоо, туршилтын зорилгоос хамаарч 0.02-0.5 га хэмжээтэй тусгаарлав. Тусгаарласан талбайн моддыг тоолохдоо ойн дундаж диаметр 6 см-ээс доош үед 1 см, 8-14 см-ийн диаметртэй үед 2 см, 16 см-ээс дээш үед 4 см-ийн үелэлээр тус тус ангилж тоолов.

Моддын тооллогыг модны төрөл, ташинга тус бүрээр гүйцэтгэв. Ойн нөөц болон дундаж өндөр, диаметр, таксацын бусад үндсэн үзүүлэлтийг тодорхойлох зорилгоор загвар модыг сорьц талбай бүрээс, бүдүүний үелэл тус бүрээс сонгон авав.

Загвар модны насыг хожуул дээрх жилийн цагиргийн тоогоор, ургаа том модныхыг “насны өрөм”-өөр тодорхойлов. Ойн дундаж өндрийг загвар модны хэмжилтийн материалыг үндэслэн өндөр, диаметрийн хамаарлын тахирмаг зурж тодорхойллоо. Ойн нөмрөг доорхи байгалийн сэргэн ургалтын явцыг тодорхойлох зорилгоор $0.5 \times 0.5$ м буюу $1.0 \times 1.0$ м хэмжээтэй тооллогын талбайг сорьц талбайд жигд байрлалтайгаар байгуулж, цухуйц, өсвөр модны тооллого хэмжилт хийв. зонхилно. Завхан аймгийн газар нутгийн 731 мянган га талбайг (ой зохион байгуулалтын материал, 2013) эзлэн ургадаг ой хөвч нь уулын ой бөгөөд Төв Хангайн гол нуруу болох Тарвагатай, Булнай зэрэг уулсаар 
тархдаг [2].

Хангайн нуруунаас эх авсан гол, горхи нь Хойт мөсөн далайн ай сав, Төв Азийн гадагшаа урсгалгүй нуур, цөөрөмд цутгадаг. Ус бүрдүүлэгч гол эх үүсвэр нь борооны ус ба жилийн урсацын 40-65\%ийг, голын усны 15-20\%-ийг цасны хайлсан ус тус тус эзлэнэ.

Төв Хангайн нутаг эрс тэс, хүйтэн уур амьсгалтай, голын хөндий, хотгоруудад $(50-55)^{\circ} \mathrm{C}$ хүртэл хүйтэрдэг ба хаврын сүүл, зуны эхээр хуурай үе тохиолддог, зун нь богинохон, сэрүүн, агаарын температур $30^{-3} 35^{\circ} \mathrm{C}$ хүрдэг, нарны гэрлийн цацрагийн баланс газрын гадаргуу дээр 35 ккал/см², олон жилийн дундаж агаарын температур $-1.9^{\circ} \mathrm{C}$. Хүйтний үед Сибирийн эсрэг циклоны хүчтэй нөлөөтэй байдаг бөгөөд Төв Хангайн ойд мод бэлтгэл эрчимтэй явагддаг тул ой, ургамалжлыг нарийвчлан судлаж, ойн ашиглалт, хамгаалалт, нөхөн сэргээлтийн менежментийн арга хэмжээг боловсруулах, хэрэгжүүлэх нэн шаардлагатай юм.

Мод бэлтгэлийн нөлөөгөөр мод огтолсон талбайн гадаргуугийн усны урсац хаврын улиралд 10-80 дахин, зуны улиралд 2-10 дахин ихэсдэг бөгөөд ялангуяа мод бэлтгэлийн цагаалгын зам огтлолтын дараах
1-2 жилд эрчимтэй элэгдэл эвдрэлд орж 42.20-59.75 т/км² хэмжээний хөрс эвдэрч, ойн ургамалжил нуга, хээрийн ургамлаар солигдон, ойн сэргэн ургалтанд таагүй нөхцөл бүрддэг болохыг судалгаагаар тогтоосон [7].

Мод нилэнхүйд нь огтолсон талбайн 200 см-ийн өндөр дэх агаарын дундаж температур зуны улиралд ой дахь температураас $0.3-1.1^{\circ} \mathrm{C}$-ээр их, газрын гадаргуугаас 20 см-ийн өндөрт 8-р сард $-5^{\circ} \mathrm{C}-7^{\circ} \mathrm{C}$ их байгаа нь ургамлын залуу мөчир, найлзуур, цухуйцыг ургамал ургалтын хугацаанд хөнөөхөд хүргэдэг (9).

Оросын эрдэмтэн Г.И.Гирс ба О.Н.Зубарев нарын судалгаагаар шинэсний вегетатив эрхтэн болох шилмүүс, нэг наст мөчир, нахиа нь $52.0^{\circ} \mathrm{C}$-д 5 минут болоход үхдэгийг тогтоосон байдаг. Иймд Төв Хангайн мод огтолсон талбайд шинэсний цухуйц урган гарах үед тохиолдох хамгийн их температур нь ойн байгалийн сэргэн ургалтанд сөрөг нөлөөтэй болно. Хүснэгт 1-ээс харахад ургамал ургалтын хугацаанд мод огтлоогүй ойн талбайн хөрсний 5-20 см гүн дэх температур нилэнхүй мод огтолсон талбайн хөрсний температураас үргэлж бага байна.

ХУснэгт 1. Мод огтлоогүй ой ба мод огтолсон ойн талбайн хөрсний янз бүрийн гүн дэх температур, ${ }^{\circ} \mathrm{C}$

\begin{tabular}{|l|l|c|c|c|c|}
\hline \multirow{2}{*}{$№$} & \multicolumn{2}{|c|}{ Хувилбар } & \multicolumn{4}{c|}{ Хөрсний гүн, см } \\
\cline { 3 - 6 } & & $5 \mathrm{~cm}$ & 10 см & 15 см & 20 см \\
\hline 1 & Мод огтлоогүй ойн талбай & $6.4-8.2$ & $5.1-6.4$ & $4.6-5.4$ & $4.0-4.9$ \\
\hline 2 & Нилэнхүй мод огтолсон талбай & $10.1-15.2$ & $9.2-12.0$ & $8.7-11.3$ & $8.5-10.6$ \\
\hline
\end{tabular}

Төв Хангайд ихэнхдээ уулын ойн цэвдэгт бүдүүн ялзмагт хөрс тархах ба ойн доод хил далайн түвшинээс дээш 1800-1900 м, заримдаа томоохон голын хөндийгөөр 1670-1700 м. Ойг бүрдүүлэгч үндсэн мод нь сибирь шинэс, багахан талбайд хуш мод тархана. Төв Хангайд өргөгдөл бүслүүрийн цогц хэвшинж илэрдэг ба (Коротков, Дугаржав, 1976; Леса МНР, 1978) тайгажуу бүслүүрийн ойд алаг өвс-ритид хөвд, ритид хөвд, алирс-ритид хөвд, сорвоо-ритид хөвд, улалж ритид хөвд, цармын бүслүүрт алирснэрс-аулакомниум хөвдөт хэвшинжийн ой тус тус зонхилдог онцлогтой. Цармын бүслүүрийн ой далайн түвшинээс дээш 2300 м-ээс эхлэх ба ойн дээд хил 2500-2600 м., энд цэвдэгт тайгын хүлэрлэг хөрстэй бөгөөд мөнх цэвдэг нь 40-50 см гүнээс эХэлнэ. 


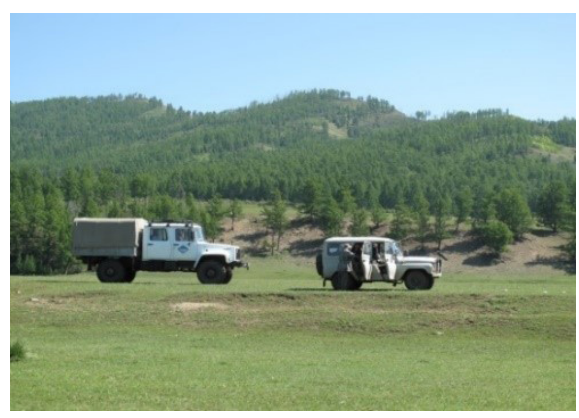

Тайгажуу ой Завхан аймаг, Тосониээнәл сум

Тайгажуу шинэсэн ойн үндсэн ташингын моддын дундаж өндөр 18-22 м, нас 150-с дээш, бүтээмж IV анги болно. Тэдгээрийн нөөц 200-300 м³/га, заримдаа $130-550 \mathrm{~m}^{3} /$ га байна.

Ойн насны бүтэц, бүрэлдэхүүний судалгаанаас үзэхэд, Төв Хангайд 180230 насны шинэсэн ой багагүй талбайд тохиолдож байгаа нь түймрийн дараа сэргэн ургасан насны нэг ангийн ой болно. Насны хэлбэлзлэлийн коэффициент 7.4\% ба ойн дундаж нас 185 жил, нэг га талбайд 1304 ширхэг мод тоологдсоноос 47.7\% нь буюу 622 ширхэг/га нь үхэж буй модод байгаа нь ойн байгалийн сийрэгжилт удаан явагдагийг илтгэж байна. Хатаж үхэж байгаа моддын диаметр 4-12 см болно.

Төв Хангайн нөхцөлд, 110-170 нас, 230-310 нас, 370-390 насны шинэс модод зонхилон ургаж байгаа нь тухайн бүс нутгийн ой янз бүрийн насных болохыг харуулна. Төв Хангайн ойн насны бүтэц нийлмэл, байгалийн аясаараа солигдсон насны 2-3 үе удмаас тогтдог, насны хэлбэлзлэлийн коэффициент $12-24 \%$ ба судалгааны талбайд тоологдсон модны 50иас илүу хувь нь 230-310 насных байгааг судалгааны дүнд тогтоосон [5]. Иймд тухайн бүс нутагт түүвэрлэх огтлолтыг ашиглах нь зүйтэй гэсэн дүгнэлтэнд хүрэв.

Суурин судалгааны үр дүнд Төв Хангайн тайгажуу шинэсэн ойн үндсэн хэвшинжүүдийн фитоценозын бүтцийг тодорхойлж, үндсэн ашиглалтын огтлолтын нөлөөн дор ойн ургах

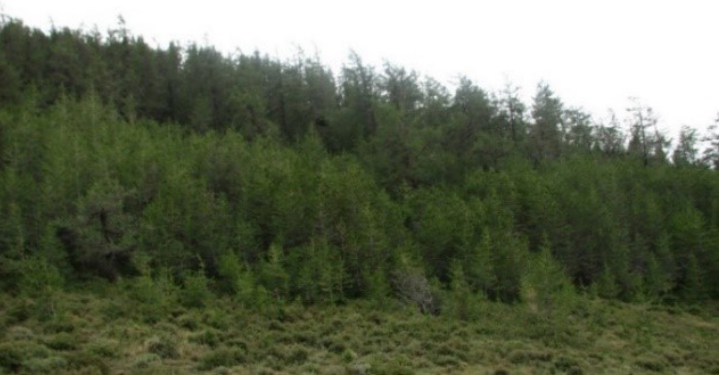

Цармынн ой. Завхан аймаг, Цагаан чулуут сум

орчин, түүний өөрчлөгдөх зүй тогтол, фитоценозын хөдлөлзүйн онцлогийг илрүүлж (Доржсүрэн, 2009) мод нэлэнхүй огтлолтоос хойш 1 жилийн дараа ценозын төсөөтэйн коэффициент $65 \%, 6$ жилийн дараа 24\%, 12 жилийн дараa 25\% байгааг тус тус тогтоов.

Байгалийн нөхөн сэргэлт муу явагдаж буй ийм ойд зориудын ойжуулалт хийхгүй бол ойн ургамалжил хээрийн экосистемд шилжих нөхцөл бүрддэг, харин сул эрчимтэй түүвэрлэн огтлолт ургамал бүрхэцэд онцгой нөлөө үзүүлэхгүй, ойн сэргэн ургах нөхцлийг сайжруулж байна [9]. Нилэнхүйд нь мод огтлолсоны дараа ойн ургамалжлын бүтэц, бүрэлдэхүүн алдагдаж, өөрчлөлтөнд орсноор нуга, хээрийн ургамлаар солигдон, ойн сэргэн ургалтанд таагүй нөхцөл бүрддэг болохыг илрүүлэв.

Төв Хангайн тайгажуу шинэсэн ойн хөвхний зузаан 3-6 см байдаг бөгөөд ойн ашиглалтаас хамааран түүний зузаан, хадгалагдах нөөц нь эрс багасаж байв. Тухайлбал, алирс-ритидиум хөвдөт ой хамгийн их хөвхний нөөцтэй 26.2 т/ га байхад хамгийн бага нөөцтэй 12.3 т/ га нь сорвоо-ритидиум хөвдөт ой, харин нилэнхүйд нь мод огтолсон хуучин талбайн хөвхний зузаан 1 см, нөөц нь 2.0-4.7 т/га байгааг судалгааны дүнд тус тус тогтоов.

Ойн ус барих чадвар нь хөвхний зузаан, нөөц, бүрэлдэхүүнээс шууд хамаардгийг (7) тогтоосон бөгөөд дээрх судалгааны дүнтэй харьцуулахад хамгийн бага хөвхний 
зузаантай, бага нөөцтэй (2.0-4.7 т/га) сорвоо ритидиум хөвдөт шинэсэн ойн ус барих чадвар хамгийн бага буюу 9.6 мм байгаа нь судалгааны үр дүнг баталгаажуулж байгаа юм.

Ойн байгалийн сэргэн ургалтын судалгаанаас үзэхэд, алирс-ритиум хөвдөт шинэсэн ойн нэг га талбайд 400 мян. ширхэг бүрэн идээтэй үр унасан боловч лабораторын соёололт нь $30 \%$, харин мод огтолсон талбай болон ойн цоорхойд 32 мян. ширхэг үр тоологдож тэдгээрийн лабораторын соёололт нь 25\% байв. Үүнээс Үзэхэд, ойн нөхөн сэргээлтийг хязгаарлагч нэгэн гол хүчин зүйл нь өвслөг ургамлын нөлөөлөл юм гэж дүгнэн намар нь ойн хөрсийг анжисаар хагалж, боловсруулсан шан дотор 3 настай шинэсний тарьцаар ойжуулсан нь илүҮ үр дүнтэй байв.

Ойн нөөцийг зүй зохистой ашиглах болон таксацын бүтэц, бүрэлдэхүүнийг сайжруулах, бүтээмжийг дээшлүүлэхэд арчилгааны огтлолт нь шийдвэрлэх үүрэгтэй. Арчилгааны огтлолтын судалгааг Завхан аймгийн Тосонцэнгэл сумын нутаг Хуурайн аманд дан бүрэлдэхүүнтэй, 47 насны шинэсэн ойд 1979 оноос эхлэн явуулав.

Залуу шинэсэн ойд явуулсан судалгааны материалыг боловсруулсан дүнгээс үзэхэд, судалгааны талбайн ойн бүрэлдэхүүн: 1 -р ташинга $7 \amalg_{(350-400)} 3 \amalg_{(200-250)}, 2-p$ ташинга $10 \amalg_{(80-85)}$, нэг га-д 6165 ширхэг амьд мод тоологдож, ойн дундаж диаметр $6.9 \mathrm{~cm}$, өндөр 7.62 м, нөөц $123.71 \mathrm{~m}^{3} /$ га байна (Хүснэгт 2).

ХУснэгт 2. Судалгааны талбайн таксаџын Үндсэн ҮзУҮлэлтүУд

Тосониээнгэл, мониторинг судалгааны 3-р иุэг (ПП-5)

\begin{tabular}{|c|c|c|c|c|c|c|c|c|}
\hline \multirow{3}{*}{ Таксацын үзүүлэлтүүд } & \multicolumn{4}{|c|}{2010 он } & \multicolumn{2}{|c|}{2015 он } & \multirow{5}{*}{ 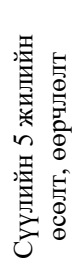 } & \multirow{5}{*}{ 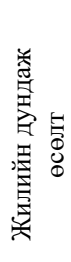 } \\
\hline & \multicolumn{6}{|c|}{ Үе удам } & & \\
\hline & I & II & \multicolumn{2}{|c|}{ III } & \multicolumn{2}{|c|}{ III } & & \\
\hline & \multirow{2}{*}{\multicolumn{2}{|c|}{ I }} & \multicolumn{2}{|c|}{ II } & \multicolumn{2}{|c|}{ II } & & \\
\hline Ойн ташинга & & & $\begin{array}{l}\text { Амьд } \\
\text { мод }\end{array}$ & $\begin{array}{c}\text { Хатсан } \\
\text { мод }\end{array}$ & $\begin{array}{l}\text { Амьд } \\
\text { мод }\end{array}$ & $\begin{array}{c}\text { Хатсан } \\
\text { мод }\end{array}$ & & \\
\hline Ойн дундаж нас (A), жил & $350-400$ & $200-250$ & \multicolumn{2}{|c|}{$75-80$} & \multicolumn{2}{|c|}{$80-85$} & & \\
\hline Модны тоо (N), шир/га & 25 & 25 & 6545 & 4460 & 6165 & 4840 & -380 & -76 \\
\hline Дундаж диаметр (Dcp), см & 52.2 & 30.8 & 6.5 & 2.1 & 6.9 & 2.1 & 0.4 & 0.08 \\
\hline Дундаж өндөр (Нср), м & 19.01 & 16.25 & 7.27 & 3.16 & 7.62 & 3.19 & 0.35 & 0.07 \\
\hline $\begin{array}{c}\text { Хөндлөн огтлолын талбайн } \\
\text { нийлбэр (G), } \text { м²/га }^{2}\end{array}$ & 5.3 & 1.9 & 21.63 & 1.57 & 23.20 & 1.75 & 1.57 & 0.31 \\
\hline Өтгөрөл (Р) & 0.16 & 0.06 & 1.02 & - & 1.04 & - & 0.02 & 0.004 \\
\hline Нөөц (M), ма $^{3}$ & 39.25 & 13.25 & 119.99 & 5.22 & 123.71 & 4.87 & 7.72 & 1.54 \\
\hline
\end{tabular}

Судалгааны талбайн таксацын үзүүлэлтүудийг $2010 \quad$ оныхтой харьцуулахад 5 жилийн хугацаанд уг талбайн нарийн диаметртэй моддоос 380 шир/га мод хатаж, ойн дундаж диаметр 0.4 см-ээр буюу жилд дунджаар 0.08 смээр, дундаж өндөр 35 см-ээр буюу жилд дунджаар 7 см-ээр тус тус өсч, ойн нөөц 7.72 $\mathrm{M}^{3} /$ га буюу жилд дунджаар 1.54 шоометрээр өссөн байгааг тогтоов.

Ойн модод ургах орчин талбайгаа хэрхэн ашиглаж байгааг илтгэн харуулдаг гол үзүүлэлт бол ойн өтгөрөл бөгөөд судалгааны дүнд ойн өтгөрөл буурах биш нэмэгдэх хандлагатайг илрүүлэв. Энэ нь уг ойд байгалийн аясаараа сийрэгжих үйл явц хэт удаашралтай илтгэж, улмаар ойн моддын өндөр, диаметр, нөөцийн өсөлт бага болохыг харуулж байна. Ойн аж ахуйн практикт ойн өтгөрөл 0.550.65 байгаа тохиолдолд ойн моддын өсөлт эрчимтэй явагдах боломжтой гэж 
Үздэг. Иймд ойн өсөлтийг сайжруулж, бүтээмжийг дээшлүүлэх зорилгоор тухайн ойд арчилгааны сийрэгжүүлэх огтлолтыг явуулах шаардлагатай.

Арчилгааны огтлолтоор 6.0 м хүртэлх өндөртэй, 5.0 смхүртэлх диаметртэй моддыг, моддын хөндлөн огтлолын талбайн $15 \%$-ийн эрчимтэйгээр огтолж

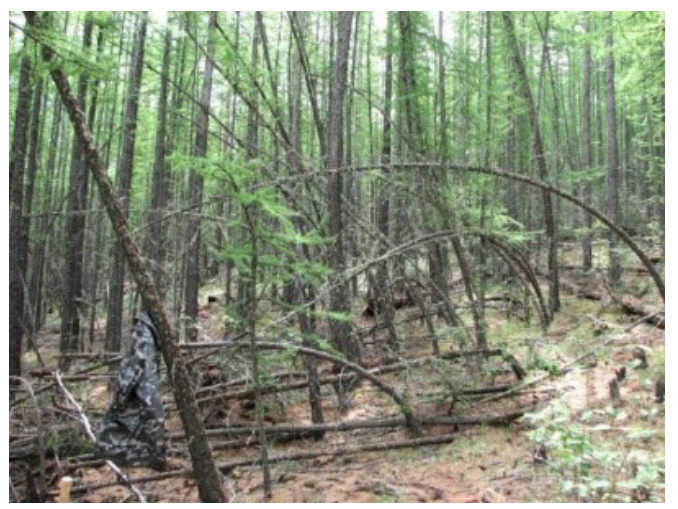

Арчилгааны огтлолт хийгээгүй ой.

Тосониэнгэл, 2015 он

Тэсийн голын гацууран ойд хийсэн судалгаанаас үзэхэд, 80-100 насны гацуур нийт ойн 80 орчим хувийг 30-40 насны гацуур 20 орчим орчим хувийг эзэлж, нэг га-д 973 ширхэг гацуур тоологдож, нэг га ойн нөөц $68.75 \mathrm{~m}^{3} /$ га, өтгөрөл 0.51 байна. Гацууран ойд өндрийн 2 ташинга илэрч, 1-p ташингын модны дундаж диаметр $18.3 \mathrm{~cm}$, өндөр 12.87 м, 2-р ташингын модны дундаж диаметр 7.1 см, өндөр 6.58 м тус тус байна. сийрэгжүүлснээр ойн дундаж диаметр 4 см-ээр, өндөр 3.0 м-ээр нэмэгдэх ба нэг гагаaс $11.05 \mathrm{~m}^{3}$ модыг авах боломжтой. Иймд Төв Хангайн дан бүрэлдэхүүнтэй 0.9-өөс дээш өтгөрөлтэй, 40-50 насны шинэсэн ойд арчилгааны огтлолтыг ойн нөөцийн $30-40$ хувийн эрчимтэй хийх нь зүйтэй гэж дүгнэв.

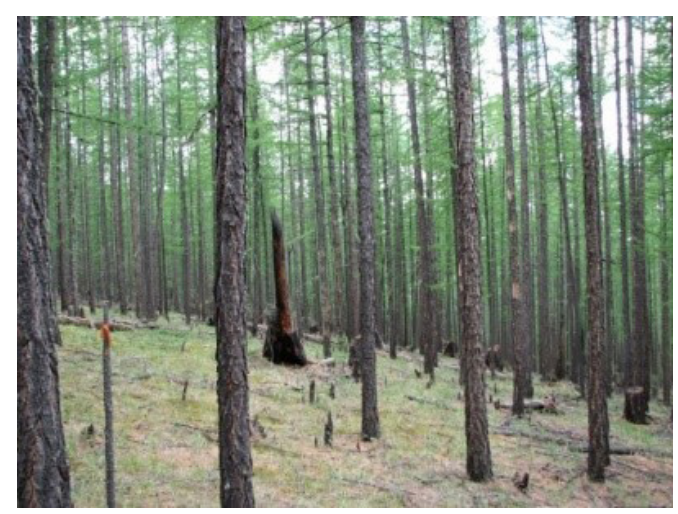

Арчилгааны огтлолт хийсэн ой.

Тосониэнгэл, 2015 он

Тэсийн голын гацууран ойн дундаж өндрийг тодорхойлох зорилгоор өндөр, диаметрийн хамаарлын тахирмаг байгуулж, холбогдох тэгшитгэлийн хэлбэрийг сонгоход, логорифм тэгшитгэл хамгийн тохиромжтой байлаа (1-p зураг). ЭнэхүY тэгшитгэлийг тухайн бүс нутгийн гацуур модны өндрийг тодорхойлоход ашиглаж болно (13).

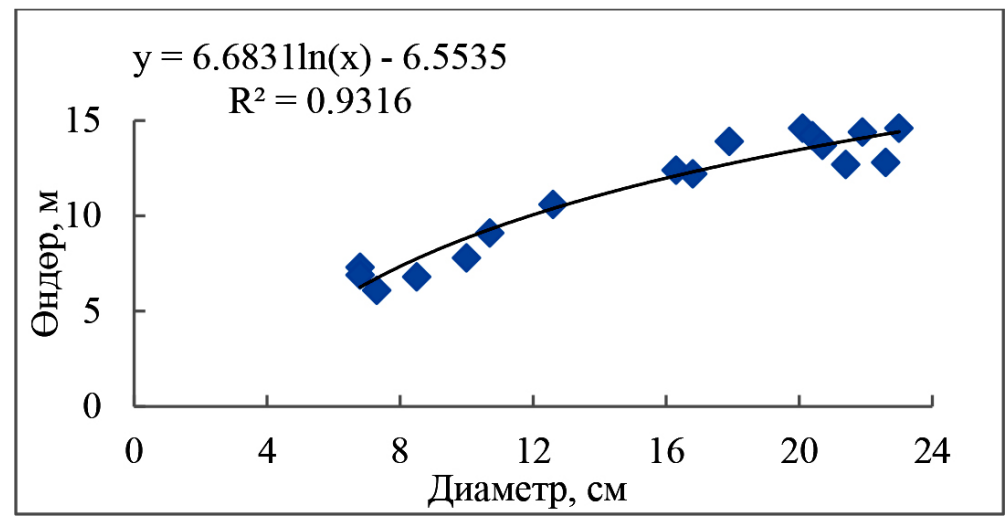

Зураг 1. Тэсийн голын бүс нутгийн гаиууран ойн өндөр, диаметрийн хамаарлын тахирмаг 


\section{2. Завхан аймгийн хээрийн}

\section{ургамалжлын судалгааны дүн}

Завхан аймгийн хэмжээнд байгалийн экосистемд нөлөөлсөн хүний хүчин зүйлсийн дийлэнх 90 орчим хувийг мал хэт бэлчээрлэлт, үлдсэн бага хувийг уул уурхай, авто замын байгууламж үзүүлж байв.

Мал хэт бэлчээрлэлт нь хөрс ургамал нөмрөгийн механик гэмтэл, эвдрэл, ялангуяа ус чийг элбэгтэй газарт дов сондуул үүсгэх, хөрсний өнгөн хэсгийг нягтруулах, давсжилт үүсгэх, хуурай газарт хөрсний өнгөн хэсгийг сийрэгжүүлэх, улам хуурайшуулах зэрэг сөрөг нөлөөллүүдийг үзүүлсэн байгаа нь ажиглагдав.

Хүний үйл ажиллагааны нөлөөллөөс гадна байгалийн, тухайлбал ус, салхины нөлөөгөөр хөрсний өнгөн хэсэг элэгдэл, эвдрэлд орох, хөрсний өнгөн хэсгийг урсгах, өнгөн хэсэг ухагдан, үе давхрагийн хөрс холилдох, ургамал нөмрөг сийрэгжих, ургамал ургах нөхцөлгүй болгох, мэрэгчдийн колони нилэнхүй үүсэх зэрэг сөрөг үр дагавруудыг бий болгожээ.

Судалгааны дүнгээс харвал, Завхан аймаг нь ургамал газарзүйн мужлалын хувьд Хангайн уулын ойт хээр, Их нууруудын хотгорын цөлөрхөг хээр, ГовьАлтайн цөлөрхөг хээрийн тойргуудад хамрагддаг учраас ургамалжлын хувьд өвөрмөц [2].

Завхан аймгийн баруун хэсгийн Ургамал, Дөрвөлжин, Сантмаргац сумдын баруун хэсэг Их нууруудын хотгорын цөлөрхөг хээрийн, Шилүүстэй, Отгон сумын баруун хэсэг, Цагаан чулуут сумдын урд хэсгээр Говь-Алтайн цөлөрхөг хээрийн, аймгийн төв, түүнээс хойших хэсэг Хангайн уулын ойт хээрийн тойрогт тус тус хамрагдаж байна.

Хээрийн судалгааны явцад хийсэн геоботаникийн дэлгэрэнгүй бичиглэлд боловсруулалт хийж, хээрийн ургамалжлын ангилааг хэвшлийн түвшинд үйлдэж, ашиглагдсан байдлаар нь зэрэглэн, үнэлгээ өгсөн болно. Үүнд: хээрийн 1 хэвшинж, өндөр уулын хээр, уулын хээр, нугын хээр, хуурай хээр, цөлөрхөг хээр, цөлийн хээр гэсэн 6 дэд хэвшинжид хамаарсан 20 хэвшил ангилав (Хүснэгт 3).

Крыловын хялганат (Stipa krylovii) хээр Завхан аймгийн бараг бүх сумдад, хамгийн хойт хилийн Баянтэс сумаас хамгийн өмнөд хил Шилүүстэй сум хүртэлх нутаг дэвсгэрийг хамруулан, д.т.д 1400-2400 м өндөрт тархах бөгөөд тэгш тал, уулын энгэр, бэл хормой зэрэг амьдрах орчинд, хөнгөн механик бүтэцтэй, элсэнцэр хөрсөнд, Завхан аймгийн баруун хэсэгт (Сантмаргаз, Ургамал, Дөрвөлжин) болон хамгийн өмнөд хэсэгт (Шилүүстэй) зэрэг сумдын нутагт сайрын (Stipa glareosa) болон (Stipa gobica) говийн хялганат формаци мөн өргөн тархалттай байна.

Байгалийн ашиглалт багатай, д.т.д 1927 м уулын бэл хормой, тэгш газраар тархах алаг өвс хялганат бүлгэмдэл 22-25 зүйл ургамалтай, бүлгэмдлийн тусгагийн бүрхэц 70\%, бүлгэмдэлд Stipa krylovii -Крыловын хялганы эзлэх хувь $40 \%$, сор 1 аривтай тархаж байна. Ийм хялганат бүлгэмдэл мал хэт бэлчээрлэлтийн нөлөөгөөр хазаар өвс (Cleistogenes squarrosa), согсоолж (Heteropappus altaica), шарилж (Artemisia dracunculus) зэрэг талхлагдлын индикатор ургамлын оролцоо, бүлгэмдэл үүсгэх үүрэг нь эрс нэмэгдсэн алаг өвс-үетэн-хазаар өвст болон өөрчлөгдсөн байх ба ийм бүлгэмдэл Сант-Маргаз, Ургамал, Дөрвөлжин сумдуудын нутагт өргөн, шарилжны (Artemisia dracunculus, A.Adamsii) Үүрэг ихсэж хялгана- алаг өвс-шарилжит (Artemisia dracunculus) бүлгэмдэл тархсан нь Идэр, согсоолжийн (Heteropappus hispidus) үүрэг нэмэгдсэн шарилж- алаг өвс- согсоолжит, шарилж-үетэн-алаг өвст бүлгэмдэл бараг бүх сумдын нутагт алаг цоог тархана.

Завхан аймагт харганат формаци өргөн тархдаг онцлогтой. Ялангуяа Caragana Bungei, C pygmaea, C. Leucophloea өндөр арвитай тохиолдох бөгөөд Caragana spino$s a$ голын эрэг, уулын энгэр, бэл хормойгоор төгөл үүсгэн тархаж байна. 
Хүснэгт 3. Завхан аймгийн хээрийн ургамалжллын ангилаа

\begin{tabular}{|c|c|c|}
\hline Хэв шинж & Дэд хэвшинж & Хэвшил \\
\hline \multirow{9}{*}{ 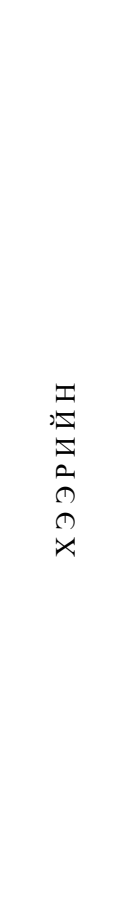 } & \multicolumn{2}{|r|}{ Өндөр уулын } \\
\hline & $\begin{array}{c}\text { Өндөр уулын } \\
\text { хээрийн }\end{array}$ & $\begin{array}{l}\text { 1.Ленийн ботуульт (Festuca lenensis) хэвшил } \\
\text { 2.Сунагар биелэгт (Poa attenuata) хэвшил } \\
\text { 3.Бушилзат (Kobresia Bellardii) }\end{array}$ \\
\hline & \multicolumn{2}{|r|}{ Бэсрэг уулын } \\
\hline & Уулын хээрийн & $\begin{array}{l}\text { 4. Ленийн ботуульт (Festuca lenensis) хэвшил } \\
\text { 5. Жижиг дэгнүүлт үетэнт хэвшил (Koeleria macrantha, Poa attenuate, Festuca } \\
\text { lenensis) } \\
\text { 6. Агьт (Artemisia frigida) }\end{array}$ \\
\hline & Нугын хээрийн & $\begin{array}{l}\text { 7. Зогдор улалжит хэвшил (Carex pediformis) } \\
\text { 8. Алаг өвст хэвшил } \\
\text { 9. Улалжит хэвшил (Carex rupestris, C.amgunensis) } \\
\text { 10. Харганат (Caragana spinosa) }\end{array}$ \\
\hline & \multicolumn{2}{|r|}{ Толгодын болон тэгш талын } \\
\hline & Хуурай хээрийн & $\begin{array}{l}\text { 11. Түнгэт хэвшил (Leymus chinensis) } \\
\text { 12. Крыловын хялганат хэвшил (Stipa krylovii) } \\
\text { 13. Дэрвээн хазаар өвст хэвшил (Cleistogenes squarrosa) } \\
\text { 14. Харганат хэвшил (Caragana bungei) }\end{array}$ \\
\hline & Цөлийн хээрийн & $\begin{array}{l}\text { 15. Сайрын хялганат хэвшил (Stipa glareosa) } \\
\text { 16. Говийн хялганат хэвшил (Stipa gobica) } \\
\text { 17. Таанат хэвшил (Allium pollyrrhizum }\end{array}$ \\
\hline & Цөлөрхөг хээрийн & $\begin{array}{l}\text { 18. Говийн хялганат хэвшил ( Stipa gobica) } \\
\text { 19. Сайрын хялганат хэвшил (Stipa glareosa) } \\
\text { 20. Орог тэсэгт хэвшил (Krashininikovia ceratoides) }\end{array}$ \\
\hline
\end{tabular}

Одой харганы (Caragana pygmae) Үүрэг эрс нэмэгдсэн харганат бүлгэмдэл Сонгино, Цагаанчулуут, Эрдэнэхайрхан зэрэг сумдад нилээд нэмэгдэж буй бөгөөд энэ чигээрээ ашиглалт үргэлжлээд байвал бэлчээрийн тэжээлийн чанар сайтай ургамлуудаас бүрдсэн хялганат бүлгэмдэл тэжээлийн чанар муу, малын муу иддэг болон иддэггүй ургамлаас бүрдсэн шарилжит бүлгэмдлээр солигдох нөхцөл бүрдсэн байгааг судлан тогтоов.

Д.т.д 2000 м-ээс дээших өндөр бүхий уулын энгэрт биелэг өвст (Poa attenuate), ботуульт (Festuca lenensis) формаци тархах ба ялангуяа ботуульт уулын хээр Алдархаан, Яруу, Эрдэнэхайрхан зэрэг сумдын нутагт хамгийн өргөн тархалттай, их талбайд, Их нууруудын хотгорын зүүн хэсэгт хамаарах Дөрвөлжин сумын баруун, баруун урд хэсэгт Горчаковын сэдэргэнэт (Convolvulus Gorchakovii), боролзойт (Ajania fruticulosa), зүҮн гарын бударганат (Reamurua soongarica), баглуурт (Anabasis brevifolia) цөлийн ургамалжил тархдаг онцлогтой. Энэ суманд мөн элсний шарилж (Artemisia Komarovii) зонхилсон бүлгэмдэл нилээд өргөн хүрээтэй тархана.

Судалгааны явцад Завхан аймгийн ургамал нөмрөг мал хэт бэлчээрлэлтийн нөлөөгөөр талхлагдсан байдлыг газар нутгаар ангилж үзвэл:

\section{Дунд, их, хэт их ашиглалттай}

\section{экосистем:}

- Хүн ам шигүү суурьшсан, хүн малын төвлөрөл болсон баг, өвөлжөө, хаваржаа, уст цэг, худаг, тунгалаг уст болон сул эрдэсжилттэй нуур зэргийн эргэн тойронд болон 7-8 км-ийн радиус доторх нутагт

- Том голууд тухайлбал, Тэс, Идэр, Хунгуй, Завхан, тэдгээрийн салбар жижиг голуудын татам, ойролцоох нам уулын бэл, энгэр, хормой, тэгш тал газрууд хамрагдаж байна. 
Бага ашиглагдсан буюу байгалийн фон экосистем:

- Суурин газар, усны эх үүсвэрээс алслагдсан бүс нутаг, өндөр уулын д.т.д 2000 м-ээс дээш уулын энгэр, хажуу бэл, хилийн бүс орчмын нутаг хамрагдаж байна.

Завхан аймагт уул уурхай одоогоор өргөн тархалттай бус, Дөрвөлжин сумын нутагт байрлах Баян-Айраг ХХК алт олборлох үйл ажиллагаа явуулж байгаа ба түүний орчмын крыловын хялганат хээр хазаар өвст (Cleistogenes squarrossa) бүлгэмдлээр солигдсон нь ажиглагдав. Сумын төвөөс урагш хувиараа алт олборлогчид байрлаж, газар сайгүй ухаж нүх үүсгэсэнээс ургамал нөмрөггүй болж багагүй талбайг талхалсан байна.

Завхан аймгийн хэмжээнд малын бэлчээрт хэт их ашиглагдсан болон талхлагдсан бэлчээр сум бүрт эзлэх талбайн хэмжээгээр харилцан адилгүй байгаа ба үүнийг сумаар ангилан үзвэл:

\section{Хэт ашиглалттай болон талхлагдсан том талбай бүхий бэлчээртэй сумд:}

Баянхайрхан сум: Агит уулын урд энгэрийн бэлчээр, Харганы голын хөндий, түүний салбар голуудын Цагаан нуурт цутгах хэсгийн бэлчээр, уулс хоорондох хөндий, мөн сумын ойролцоох уулсын бэлчээр

Алдархаан сум: Чигэстэй, Богдын голын хөндийн баруун эргийн ургамалжил, Үүнд ойролцоох нам уулс, уулс хоорондох хөндийн бэлчээр

Цагаанчулуут сум: уулс хоорондох хөндийн бэлчээр, ялангуяа сумын төвөөс зүүн урд байрлах уулс, тэдгээрийн хоорондох хөндийн бэлчээр.

Улиастай сум орчмын болон Ганцын давааны орчмын бэлчээр (д.т.д 2550 м) зэрэг нутаг дэвсгэрийн бэлчээр, ургамалжил мал бэлчээрлэлтийн нөлөөнд хэт их автсан, талхлагдсан зэрэглэлд хамрагдаж байна.

Хэт их ашиглалттай болон талхлагдсан бага талбай бүхий бэлчээртэй сумд:

Тосонцэнгэл сумын зүүн урд байрлах уулын хойш харсан энгэрийн ургамалжил, бэлчээр

Түдэвтэй сумын Ойгон нуурын болон ойролцоох уулс хоорондох хөндийн бэлчээр

Сонгино сумын баруун, зүүн талд байрлах уулс хоорондох хөндий

Нөмрөг сумын Тэлмэн нуурын баруун Хэсэг

Тэлмэн сумын Идэр голын зүүн эрэг, дэнж, сум орчмын жижиг нам уул, толгодын тэгш орой хэсэг

Завханмандал сумын Завхан голын хөндий

Шилүүстэй сумын умард хэсгийн уулс хоорондох, Яруу сумын Хаг нуурын хөндий зэрэг тодорхой бүс нутгаар мал хэт бэлчээрэлэлтийн нөлөөгөөр талхлагдсан экосистемүүд оршиж байна.

Завхан аймгийн баруун талын Эрдэнэхайрхан, Завханмандал, Сантмаргаз, өмнөд хэсгийн Цагаанхайрхан, Отгон, Шилүүстэй сумдын нутгаар Allium төрлийн зүйлүүд Allium polyrrhyzum, A.mongolicum, A.anisopodium, A. odorum зэрэг зүйлүүд маш өргөн тархалттай, cop1, сор2 аривтайгаар зонхилогч, дэд зонхилогчийн түвшинд тархаж байв.

Засмал зам тавьж буй асуудалтай холбоотой ухаж, эвдсэн экосистем Тосонцэнгэл сумын нутагт Идэрийн голын зүүн хөндийд, харин байгалийн гаралтай, тухайлбал үлийн цагаан оготоны нөлөөтэй, маш том колони үүсгэсэн, ургамал нөмрөггүй шахам болсон, үлийн цагаан оготоны идэш тэжээл болох нэг наст лууль, хамхуул зонхилсон талхлагдсан экосистем Нөмрөг, Тэлмэн, Тосонцэнгэл, Алдархаан, Цагаанчулуут зэрэг сумдад тархаж байна.

Өнөөдөр хагалж тариалсан газар Баян тэс сум, Асгат багийн тодорхой бүс нутагт, 30 -аад жилийн өмнө тариалж байгаад орхигдсон атаршсан газар Тэс, Тэлмэн, Нөмрөг, Цагаан чулуут сумдын нутагт тохиолдсон ба тэдгээрийн байгалийн нөхөн сэргэлт сайн явагдаж байна гэсэн дүгнэлтэнд хүрэв. Талхлагдсан бэлчээр, атаршсан газрын байгалийн нөхөн сэргэлт 
нэг наст хог ургамлын үе, шарилжийн үе, хиаг-жижиг дэгнүүлт үетэний үе, байгалийн ургамлын түрэн ургах үе гэсэн тодорхой үе шаттуудыг дамждаг ба эдгээр 30 гаруй жилийн өмнө орхигдож, атаршсан газрын бэлчээрийн нөхөн сэргэлт сайн явагдаж байв. Тухайлбал, Тэлмэн сумын атаршсан газарт шарилжны үе дуусаж хиагний үе эхэлж, шарилж-хиагт бүлгэмдэл, Нөмрөг сумын нутагт үетэн-шарилж хиагт бүлгэмдэл бүрэлдэн тогтож, байгалийн тэжээлийн үндсэн ургамал болох хялгана, ерхөг зэрэг үетэн, алаг өвснүүд түрэн ургаж эхэлсэн байгаа нь байгалийн нөхөн сэргэлт сайн явагдаж буйн илрэл юм.

Баянтэс, Их уул, Тосонцэнгэл, Идэр, Отгон, Цагаанхайрхан зэрэг сумдын
Хангайн нурууны өндөр уулын болон тайгын бүслүүрийн ургамалжил, Эрдэнэхайрхан, Яруу сумдын зүүн урд хэсгийн хээрийн ургамалжил, Дөрвөлжин сумын нутагт тархах цөлөрхөг болон цөлийн бүсийн ургамалжил өөрчлөлт багатай, 1-р ангилал буюу сайн үнэлгээнд хамрагдаж байв. Завхан аймгийн сумдын хээрийн экосистемийн нөлөөллийн үнэлгээг сум тус бүрээр үнэлсэн үнэлгээг Хүснэгт 4энд нэгтгэн үзүүллээ. Хүснэгтээс харахад Тэс, Асгат, Сонгино, Ургамал зэрэг сумдын хээрийн экосистем 3-5 баллын үнэлгээтэй буюу их, хэт их, талхлагдсан ангилуудад хамрагдаж байв. Завхан аймгийн хэмжээнд хээрийн экосистемийн ашиглалт 3 баллын буюу дунд үнэлгээнд хамрагдав.

Хүснэгт 4 Завхан аймгийн хээрийн экосистемийн үнэлгээ (баллаар)

\begin{tabular}{|c|c|c|}
\hline № & Сумын нэр & Үнэлгээ \\
\hline 1. & Тэс & 4 \\
\hline 2. & Баян-Тэс & $1+2+3$ \\
\hline 3. & Асгат & 5 \\
\hline 4. & Баян-хайрхан & 3 \\
\hline 5. & Сонгино & 4 \\
\hline 6. & Цэцэн-Уул & 3 \\
\hline 7. & Түдэвтэй & 3 \\
\hline 8. & Нөмрөг & $3+4$ \\
\hline 9. & Тэлмэн & $2+3$ \\
\hline 10. & Тосон-Цэнгэл & $3+4$ \\
\hline 11. & Их-Уул & $1+3$ \\
\hline 12. & Идэр & 3 \\
\hline 13. & Яруy & $3+5$ \\
\hline 14. & Алдархаан & $2+3+5$ \\
\hline 15. & Цагаан-хайрхан & $2+3$ \\
\hline 16. & Отгон & 3 \\
\hline 17. & Шилүүстэй & 3 \\
\hline 18. & Цагаан-Чулуут & $2+3+5$ \\
\hline 19. & Эрдэнэ-Хайрхан & $2+3$ \\
\hline 20. & Завхан-мандал & 3 \\
\hline 21. & Сант-маргаз & 3 \\
\hline 22. & Ургамал & $3+4$ \\
\hline 23. & Дөрвөлжин & $3+4$ \\
\hline
\end{tabular}




\section{ДҮГНЭЛТ}

Завхан аймгийн ой, хээрийн экосистемийн нөлөөллийн үнэлгээний судалгааны дүнд дараах үр дүнд хүрэв. Үүнд:

- Завхан аймгийн нутагт Монгол улс төдийгүй дэлхийд ховорхон тайгажуу бүслүүрийн ой тархан ургадаг онцлогтойг тогтоов.

- Тайгажуу шинэсэн ойн экологи, өсөлт, хөгжилтийн онцлогийг харгалзан ойн аж ахуйн менежментийн үйл ажиллагааг шинжлэх ухааны үндэслэлтэйгээр явуулах нь зүйтэй.

- Шинэсэн ойн өсөлтийг дээшлүүлэх, бүтээмжийг нэмэгдүүлэхэд арчилгааны сийрэгжүүлэх огтлолт зайлшгүй шаардлагатай.

- Шинжлэх ухааны үндэслэлтэйгээр Тэсийн голын гацууран ойг хамгаалах, нөхөн сэргээх, арчилгаa, цэвэрлэгээг явуулах нь зүйтэй.

- Завхан аймгийн хээрийн 1 хэвшинж, 6 дэд хэвшинж, 20 хэвшлийг ялгав.

- Завхан аймгийн хээрийн экосистемд анхан шатны нөлөөллийн үнэлгээ өгч, үнэлгээний 3 балл буюу дунд үнэлгээнд хамруулав.

- Завхан аймгийн экосистемд нөлөөлөгч хүчин зүйлс нь байгалийн (ус, салхины, үлийн цагаан оготоны) болон хүний хүчин зүйлсийн (мал хэт бэлчээрлэлт, уул уурхайн ашиглалт, түймэр, авто замын байгууламж) зэрэг байв.

- 30 гаруй жилийн туршид атаршсан газрын байгалийн нөхөн сэргэлт хэвийн түвшинд явагдаж шарилж-хиагт болон үетэн-шарилж-хиагт бүлгэмдэл болон нөхөн сэргэж буйг тогтоов.

\section{Ашигласан бүтээлийн жсагсаалт}

1. Анучин П. Н. 1977, Лесная таксачия. 5-е изд., доп. - М.: Лесн. пром-сть, 1982. - 550 с.

2. Ганболд Э. Флора Северной Монголии. Москва, 2010. 254 с

3. Гирс Г.И., Зубарев О.Н. 1979, Устойчивость вегетативных органов хвойных $к$ высокой температуре. В кн.: Реакиия хвойных на действие повреждающих факторов. Красноярск, с. 5-14.

4. ГомболҮҮдэв П. Завхан аймгийн иаг уурын өөрчлөлт, ирээдүйн хандлага. 2012. 11.18

5. Должсинсүрэн М ба бусад Завхан аймгийн цаг агаарын аюултай узэгдлүүдийн хувьсал, өөрчлөлт. 2012. www.icc.mn/aimag/Zavkhan/

6. Дугаржав Ч. Монгол орны шинэсэн ой. 2006, УБ, Бэмби сан, 318 x.

7. Доржсурэн Ч. 2009, Антропогенные сукиессии в лиственничных лесах Монголии. М.: $260 \mathrm{c}$.

8. Краснощеков Ю.Н. 1980, О почвозащитной роли псевдотаежных лиственничников в Центральном Хангае. В кн.: Современные аспекты изучения эрозионных процессов. Новосибирск, с. 166-170.

9. Коротков И., Дугаржав Ч. 1976, Закономерности распределения лесов в Монгольской Народной Республике. Бот. ХҮр. Бүтээл № 1, УБ, х. 162-185.

10. Леса МНР (лиственничные леса Центрального Хангая). 1983, Новосибирск, Наука, $148 \mathrm{c}$.

11. Методология оченки состояния и картографирования экосистем в экстремальных условиях, 1993, Москва,

12. Ой зохион байгуулалтын материал. 2013 он. БОНХЯ-ны Ойн судалгаа хөгжлийн төв.

13. Побединский А. В. 1962, Изучение лесовосстановительных процессов. Красноярск, $63 \mathrm{c}$. 


\begin{abstract}
We classified the steppe of Zavkhan aimag on steppe type and 6 subtypes : high mountain steppe, mountain steppe, meadow steppe, dry steppe, desertified steppe ans desert steppe and 20 formations. In result of study, by degree of influence on steppe ecosystem Zavkhan aimag evaluated at 3 points or middle stage of influence on steppe ecosysytem.
\end{abstract}

